\title{
Gas-Phase Conversion of Glycerol to Acetol: Influence of Support Acidity on the Catalytic Stability and Copper Surface Properties on the Activity
}

\author{
Tiago Pinheiro Braga, ${ }^{*, a}$ Nadine Essayem, ${ }^{*, b}$ Swamy Prakash ${ }^{b}$ and Antoninho Valentinic \\ ${ }^{a}$ Laboratório de Peneiras Moleculares (LABPEMOL), Instituto de Química, Universidade Federal \\ do Rio Grande do Norte, Lagoa Nova, 59072-970 Natal-RN, Brazil \\ ${ }^{b}$ Institut de Recherche sur la Catalyse et l'Environnement de Lyon, IRCELYON, CNRS, University of \\ Lyon 1, 2 avenue Albert Einstein, 69626 Villeurbanne, France \\ ${ }^{c}$ Laboratório de Adsorção e Catálise (Langmuir), Departamento de Química Analítica e \\ Físico-Química, Universidade Federal do Ceará, Campus do Pici, 60455-970 Fortaleza-CE, Brazil
}

\begin{abstract}
Mesoporous mixed copper-aluminum oxides and copper-silicon oxides were synthesized with polymeric precursors route in order to evaluate the effect of the support acidity on the catalytic stability due to the carbon deposit and the copper surface characteristics on the catalytic activity for the gas-phase conversion of glycerol to acetol. The samples were characterized by different techniques such as inductively coupled plasma (ICP), thermogravimetry and differential thermal analyses (TGA-DTA), X-ray diffraction (XRD), X-ray photoelectron spectroscopy (XPS), N2 adsorption/desorption isotherms, temperature-programmed reduction with $\mathrm{H}_{2}\left(\mathrm{H}_{2}-\mathrm{TPR}\right)$ and microcalorimetry of $\mathrm{NH}_{3}$ adsorption. The metallic copper surface was shown by XPS, which was observed an increase with the copper loading without marked changes between Si or Al support using the same copper content. The $\mathrm{Cu}-\mathrm{Al}$ catalysts present acidic properties close to that of the pure alumina support while the $\mathrm{Cu}-\mathrm{Si}$ solid is not acid, as expected. Reduced catalysts were evaluated in the reaction of glycerol conversion. The catalytic results showed a clear dependence of the glycerol conversion to acetol with the $\mathrm{Cu}$ metal surface and the initial catalytic properties did not depend on the support acidity, since the copper is the major active site. It was observed $95 \%$ of acetol selectivity and $80 \%$ of glycerol conversion for the best catalyst. However, the support acidity influenced the catalyst stability, since $\mathrm{Cu}-\mathrm{Al}$ solid deactivated continuously by contrast to $\mathrm{Cu}-\mathrm{Si}$ sample, which reached stability after $2 \mathrm{~h}$ of reaction. The higher acidity for the Al support leads to a greater carbon deposit compared to Si support, blocking the active sites and providing a rapid catalytic deactivation.
\end{abstract}

Keywords: copper catalysts, support acidity, catalytic stability, glycerol conversion, acetol formation

\section{Introduction}

The conversion of renewable resources, such as plant biomass, to produce fuels and chemicals, has become an important research topic in catalysis. ${ }^{1,2}$ The utilization of biomass as renewable resources is an issue to move our economy towards a more sustainable future. The produced amounts of renewable biomass fuels, such as fatty acid methyl esters biodiesel fuel, are still increasing year by year. ${ }^{3}$ Thus, glycerol, which is the byproduct of the biodiesel production process by transesterification of

*e-mail: tiagoquimicaufrn@gmail.com, nadine.essayem@ircelyon.univ-lyon1.fr vegetable oil, can be considered as a renewable feedstock to produce chemicals of economic interest, such as acetol, propylene glycols or acrolein, which are usually made from fossil resources. ${ }^{4-6}$

Glycerol conversion was extensively studied in liquid phase to produce propylene glycols over metallic catalysts, $\mathrm{Ru}, \mathrm{Pt}, \mathrm{Ni}, \mathrm{Cu}^{7,8} \mathrm{Gas}$ phase studies are more recent and have attracted increasing attention due to the possibility to obtain, in these conditions, acrolein by removing two water molecules from glycerol. ${ }^{9,10}$ Hydroxyacetone, also named acetol, is another chemical obtained from glycerol dehydration acquired by removing one water molecule. This compound is also of interest since, via hydrogenation step, 1,2-propanediol is obtained (Scheme 1). Acetol is 
reported to be formed in high selectivity when the reaction is conducted in gas phase.

Two types of catalytic systems were described to be efficient for the selective glycerol conversion to acetol in gas phase: monofunctional acid or basic catalysts and copper based materials.

At temperatures above $300{ }^{\circ} \mathrm{C}$, acetol was obtained from glycerol over monofunctional acid catalysts such as $\mathrm{ZrS}, \mathrm{ZrW}, \mathrm{ZrWSi}$, ZrWAl. A high yield in acetol of $74 \%$ was achieved over ZrWAl at full glycerol conversion. The authors proposed that weak acid sites were the actives ones. ${ }^{11}$ Silica-aluminum catalysts, known for their acidic properties, were also reported as efficient catalyst for acetol formation at temperatures higher than $300{ }^{\circ} \mathrm{C} .{ }^{12}$ In that case, the authors have correlated the acetol selectivity to the presence of strong Lewis acid sites as well as the basic $\mathrm{OH}$ groups. Similarly, monofunctional basic catalysts were also disclosed to catalyze acetol formation in high yield at a reaction temperature as high as $360{ }^{\circ} \mathrm{C} .{ }^{13}$

By contrast to acido-basic materials, copper based catalysts were disclosed to dehydrate glycerol into acetol in milder conditions, typically between $230-250{ }^{\circ} \mathrm{C}$, at atmospheric pressure. In most cases, the metallic copper function is combined to acido-basic supports, and these bifunctional catalytic systems are reported to be efficient as well in $\mathrm{N}_{2}$ or $\mathrm{H}_{2}$ atmosphere. Copper chromite was earlier identified as one of the most active catalysts for converting glycerol to acetol. ${ }^{14-16}$ This is well exemplified by the selective dehydration of glycerol over $\mathrm{CuCrO}$ combined with the reactive distillation technology leading to acetol yields higher than $90 \% .^{17,18}$ The authors had already underlined that higher acetol yields were observed under $\mathrm{H}_{2}$ atmosphere compared to $\mathrm{N}_{2}$. Moreover, copper chromite was reported as an active system to directly produce 1,2-propanediol in $\mathrm{H}_{2}$ atmosphere. ${ }^{19}$ The authors proposed that the high acidity of $\mathrm{CuCrO}$ is responsible for the first step of glycerol dehydration to acetol.
Due to the toxicity of $\mathrm{Cr}$, alternative $\mathrm{Cu}$ based catalysts were investigated for this application. $\mathrm{Cu} / \mathrm{ZnO}$ combined with various supports, $\mathrm{Al}_{2} \mathrm{O}_{3}, \mathrm{TiO}_{2}, \mathrm{ZrO}_{2}$ were studied in order to investigate any synergistic effects between metallic copper and the oxide support on the gas phase glycerol dehydration in $\mathrm{H}_{2}$ atmosphere. ${ }^{20}$ The authors proposed different route to produce 1,2- or 1,3-propanediols, but both routes involves a first acid catalyzed dehydration step via protonation of the primary or secondary hydroxyl group followed by a hydrogenation step into 1,2- or 1,3-propanediols, promoted by the metallic copper. Under $\mathrm{H}_{2}, \mathrm{Cu}-\mathrm{H}_{4} \mathrm{SiW}_{12} \mathrm{O}_{40} / \mathrm{SiO}_{2}$ was shown to directly convert glycerol in 1,3-propanediol via proposed reaction pathway, which involves a first dehydration step of glycerol in 3-hydroxypropanal promoted by the acid sites and a further hydrogenation step of 3-hydroxypropanal catalyzed by the $\mathrm{Cu}$ sites. ${ }^{21}$ Interestingly, the authors showed that in mild conditions $\left(210{ }^{\circ} \mathrm{C}\right), \mathrm{H}_{4} \mathrm{SiW}_{12} \mathrm{O}_{40} / \mathrm{SiO}_{2}$ catalyzed glycerol dehydration in acrolein in high yield, while $\mathrm{Cu}$ didn't catalyze glycerol dehydration in 3-hydroxypropanal, the first dehydration step which could further produce acrolein via further dehydration step. One can remark that the dehydration of glycerol to 3-hydroxypropanal fits well with a BrØnsted acid catalyzed step where the secondary hydroxyl group of glycerol is protonated, leading to a secondary intermediate carbenium ion, much more stable than the primary one, which would be formed via protonation of the primary hydroxyl groups (Scheme 2).

Copper based systems were also reported to be efficient in $\mathrm{N}_{2}$ atmosphere. In particular, Sato et al. ${ }^{21}$ reported that acetol was produced from glycerol in high selectivity over $\mathrm{Cr}$ free supported $\mathrm{Cu}$ catalysts, but under $\mathrm{N}_{2}$ atmosphere at moderate temperature, $250{ }^{\circ} \mathrm{C}$. They found that the acid-base properties of the supports affected the acetol selectivity, while basic supports decreased glycerol conversion and acetol selectivity, acid supports promoted acetol selectivity. The authors concluded that the reaction of
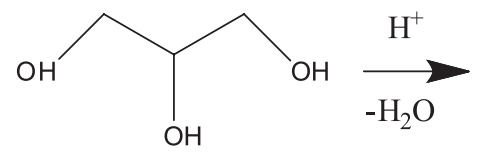

$\mathrm{H}^{+}$<smiles>CCCCC</smiles><smiles>CC(=O)CO</smiles>

acetol

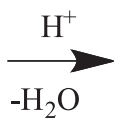

3-hydroxypropanal

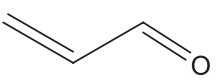

acrolein

Scheme 1. Conversion of glycerol to acetol or acrolein. 


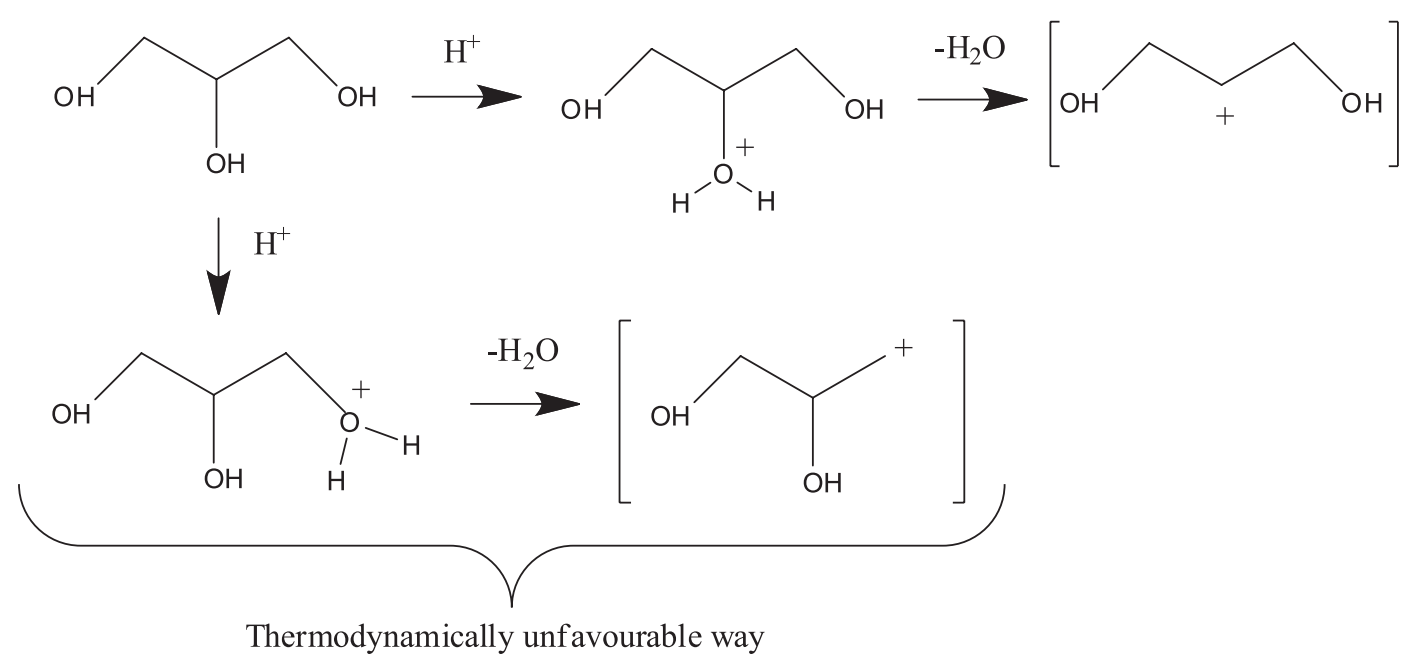

Scheme 2. Mechanism for the glycerol dehydration using acid catalysts.

glycerol conversion over $\mathrm{Cu} / \mathrm{Al}_{2} \mathrm{O}_{3}$ is not only catalyzed by $\mathrm{Cu}$, but the acid support should assist the metallic function. Thus, they first proposed that acetol formation over $\mathrm{Cu}$ based catalysts might proceed via a homolytic dissociation of the primary $\mathrm{C}-\mathrm{OH}$ bond to produce acetol. Recently, the mechanism proposed by Sato et al..$^{21}$ was supported by the results obtained by Bienholz et al. ${ }^{22}$ over $\mathrm{Cu} / \mathrm{SiO}_{2}$ in gas phase at $250{ }^{\circ} \mathrm{C}$, in $\mathrm{H}_{2}$ atmosphere. Indeed, the authors observed a linear relationship between the copper surface and the TOF, indicating that copper is primarily responsible for the glycerol conversion to acetol and the acidic, basic or neutral supports have a secondary role. ${ }^{21,22}$

From this brief literature overview, it is clear that $\mathrm{Cu}$ based catalysts are efficient catalytic systems to promote selective glycerol conversion to acetol formation in gas phase, but it also appears that there is no agreement on the nature of the active sites nor on the prevailing mechanism and on the catalysts deactivation.

In other respects, in order to improve the performances of oxides catalysts, involving copper supported ones, intense researches are currently carried out in order to develop new methodologies for material synthesis with a focus on enhanced surface area, mesoporosity and narrow pore distribution. ${ }^{23-25}$ Among them, aluminum and silicon oxide compositions are of great interest due to strong potential as catalyst supports..$^{15}$

The polymeric precursor method derived from the Pechini method is one of this methodology, allowing the synthesis of mesoporous oxides. ${ }^{16}$ Accordingly, due to the potential of this synthesis method, ${ }^{17,26}$ in this paper, we present interesting results on the transformation of glycerol to 1-hydroxyacetone over mesoporous copper-silica or copper-aluminium systems obtained by the polymeric precursor route and it was studied the effect of the support acidity $(\mathrm{Al}$ or $\mathrm{Si}$ ) on the catalytic stability due to the deposited coke and the influence of copper surface aspects on the catalytic activity.

\section{Experimental}

\section{Catalyst preparation}

This method is based on the chelation of metallic cations $\left(\mathrm{Cu}^{2+}, \mathrm{Si}^{4+}\right.$ and $\left.\mathrm{Al}^{3+}\right)$ by citric acid (CA) in a water solution followed by a polyesterification of the remaining carboxylic acid function with ethylene glycol. Aluminum nitrate nonohydrate $\left\{\mathrm{Al}\left(\mathrm{NO}_{3}\right)_{3} \cdot 9 \mathrm{H}_{2} \mathrm{O}\right\}$, copper nitrate trihydrate $\left\{\mathrm{Cu}\left(\mathrm{NO}_{3}\right)_{2} \cdot 3 \mathrm{H}_{2} \mathrm{O}\right\}$, tetraethylorthosilicate (TEOS), citric acid monohydrate (CA) $\left\{\mathrm{C}_{6} \mathrm{H}_{8} \mathrm{O}_{7} \cdot \mathrm{H}_{2} \mathrm{O}\right\}$, and ethylene glycol (EG) $\left\{\mathrm{C}_{2} \mathrm{H}_{6} \mathrm{O}_{2}\right\}$ were used as starting chemicals. A CA/metal ratio of 2:1 (mol) was used for all the samples. The metal amount is the sum of $\mathrm{Cu}, \mathrm{Al}$ or $\mathrm{Si}$. The mass ratio of CA/EG was kept at 2:3. The different samples were labeled as $\mathrm{xCuSi}$ or $\mathrm{xCuAl}$, with $\mathrm{x}$ denoting the $\mathrm{Cu}$ molar percentage $(100 \times \mathrm{Cu} / \mathrm{Al}+\mathrm{Cu}$ or $100 \times \mathrm{Cu} /$ $\mathrm{Si}+\mathrm{Cu}$ ). The sample containing only aluminum oxide was denominated $\mathrm{Al}$.

For the synthesis process of the $3 \mathrm{CuAl}$ sample, where 3 is the $\mathrm{mol} \%$ of $\mathrm{Cu} /(\mathrm{Cu}+\mathrm{Al}), 0.0038$ and $0.110 \mathrm{~mol}$ of $\mathrm{Cu}$ and $\mathrm{Al}$ salts, respectively, were dissolved in distilled water at room temperature. CA $(0.2312 \mathrm{~mol})$ was dissolved in ethanol at $50{ }^{\circ} \mathrm{C}$. Then the aqueous solution was added to the CA-ethanol solution and stirred during $60 \mathrm{~min}$ at $50^{\circ} \mathrm{C}$. Subsequently, the EG $(0.3497 \mathrm{~mol})$ was added, and the mixture was stirred for $4 \mathrm{~h}$ at $100^{\circ} \mathrm{C}$ until it became a viscous resin. The resin was treated at $300^{\circ} \mathrm{C}$ for $1 \mathrm{~h}$ under air. The resulting precursor composite was ground and treated at $500{ }^{\circ} \mathrm{C}$ under air flow for $2 \mathrm{~h}$. Similar conditions were used to prepare the other samples $1 \mathrm{CuAl}, 7 \mathrm{CuAl}$, $8 \mathrm{CuSi}$ and $\mathrm{Al}$. 


\section{Catalysts characterizations}

The solids were analyzed by inductively coupled plasma-atomic emission spectrometry (ICP-AES) after dissolution by acid attack. The analyzed $\mathrm{Cu}$ contents by ICP are the expected ones (Table 1).

The pyrolysis step was monitored by thermogravimetric analysis (TGA) and differential thermal analysis (DTA), using a $5{ }^{\circ} \mathrm{C} \mathrm{min}^{-1}$ heating rate, under air flow of $40 \mathrm{~mL} \mathrm{~min}^{-1}$ and $30 \mathrm{mg}$ of sample. The crystal structure of the metal oxides was characterized by $\mathrm{X}$-ray diffraction analysis (XRD), with $\mathrm{Cu} \mathrm{K} \alpha$ irradiation source $(\lambda=1.540 \AA$, $40 \mathrm{kV}$ and $40 \mathrm{~mA}$ ).

Catalysts specific surface area (BET) and pore volume were determined by $\mathrm{N}_{2}$ adsorption/desorption isotherms, at liquid nitrogen temperature. The catalyst samples (80 mg) were vacuum pretreated at $200{ }^{\circ} \mathrm{C}$ for $1 \mathrm{~h}$.

The acid properties were measured by calorimetry of $\mathrm{NH}_{3}$ adsorption at $80{ }^{\circ} \mathrm{C}$, using a Tian-Calvet calorimeter coupled with a volumetric equipment. The reduced solids $(0.1 \mathrm{~g})$, placed in the calorimetry cell, were first vacuum treated at $400{ }^{\circ} \mathrm{C}$ for $2 \mathrm{~h}$. After the pre-treatment, the cell was then introduced in the calorimeter at $80{ }^{\circ} \mathrm{C}$ and the experiment was performed. The oxide samples were then contacted with small doses of $\mathrm{NH}_{3}$ up to equilibrium and the differential enthalpy of adsorption was recorded together with the amount of adsorbed ammonia.

X-Ray photoelectron spectroscopy (XPS) analysis were performed on the calcined samples and after in situ reduction at $250{ }^{\circ} \mathrm{C}$, in equipment connected to the XPS spectrometer. The XPS analyses were carried out on a Kratos Ultra DLD spectrometer using monochromated $\mathrm{Al} \mathrm{K} \alpha$ radiation $(10 \mathrm{~mA}, 15 \mathrm{kV})$. All spectra were taken in the hybrid (combined electrostatic and magnetic lens) mode. All spectra were referenced to the $\mathrm{C} 1 \mathrm{~s}$ line at binding energy $284.6 \mathrm{eV}$, characteristic of ever-present adventitious carbon $(\mathrm{C}-\mathrm{C}$ and $\mathrm{C}-\mathrm{H})$. This peak position was obtained after Shirley background subtraction and decomposition of the C1s peak envelope using a Gaussian-Lorentzian (70-30\%) curve fit. All other photoelectron peaks were background-subtracted and curve-fit in the same manner. Quantification was carried out with the VISION software supplied. The relative sensitivity factors (RSF) applied here are inherent to this software and incorporate Wagner photoelectron cross-sections and analyser transmission correction.

The temperature of reduction for the $\mathrm{CuO}$ based catalysts was obtained by temperature-programmed reduction $\left(\mathrm{H}_{2}\right.$-TPR) analysis from 25 to $930{ }^{\circ} \mathrm{C}$ in a quartz reactor using a $8 \% \mathrm{H}_{2} / \mathrm{N}_{2}$ mixture $\left(25 \mathrm{~mL} \mathrm{~min}^{-1}\right)$ at a heating rate of $10^{\circ} \mathrm{C} \mathrm{min}-1$ and $20 \mathrm{mg}$ of the catalyst. A thermal conductivity detector was used to follow the $\mathrm{H}_{2}$ consumption.

\section{Catalytic activity}

Catalytic tests were carried out in a fixed bed microreactor, using $200 \mathrm{mg}$ of catalyst. All fresh catalysts were firstly reduced in $\mathrm{H}_{2}\left(25 \mathrm{~mL} \mathrm{~min}^{-1}\right)$ at $250{ }^{\circ} \mathrm{C}$ for $1 \mathrm{~h}$. Then, an aqueous solution of glycerol at $10 \mathrm{wt} \%$ was pumped at the feed rate of $1.8 \mathrm{~cm}^{3} \mathrm{~h}^{-1}$, then vaporized and fed through the reactor in a down flow mode together with a gas (hydrogen) flow rate of $25 \mathrm{~mL} \mathrm{~min}^{-1}$. The glycerol feed corresponded to $0.06 \mathrm{~mol}$ of glycerol per hour. The liquid products were collected in an ice-water-salt trap $\left(-6{ }^{\circ} \mathrm{C}\right)$ in order to be analyzed, every hour by the gas chromatography-mass spectrometry (GC-MS). A gas chromatography-flame ionization detector (GC-FID) was connected to the gas effluent. The capillary column was purchased from Varian, CP 9048 (length: 30 m, diameter: $0.32 \mathrm{~mm}$, thickness of the stationary phase: $0.1 \mathrm{~mm}$ ). Carbon balances were between 77 and $88 \%$ in the catalytic experiments. Glycerol conversion and acetol selectivity were calculated in the following way:

$$
\begin{aligned}
& \mathrm{C}_{\text {glycerol }}=\frac{\text { Amount of glycerol consumed }}{\text { mol }} \\
& \mathrm{S}_{\text {acetol }}=\frac{\text { Amount of obtained acetol }_{\text {mol }}}{\text { Amount of glycerol consumed }_{\text {mol }}} \times 100
\end{aligned}
$$

\section{Results and Discussion}

\section{Thermal analysis}

Figure 1 shows the TGA-DTA curves of the precursor powder that were obtained after heating the synthesized polymeric resin at $300{ }^{\circ} \mathrm{C}$ for 1 hour in air. The first weight loss $\left(100-150^{\circ} \mathrm{C}\right)$ is ascribed to the release of physisorbed water and remaining ethylene glycol (organic precursor). This event corresponds to an endothermic peak in the DTA curve. The main weight loss is observed from 300 to $500{ }^{\circ} \mathrm{C}$ for the $\mathrm{Cu}-\mathrm{Al}$ samples. For the $\mathrm{Cu}$ free sample, $\mathrm{Al}$, or $8 \mathrm{CuSi}$ the weight losses was prolonged at higher temperature, 550 and $600{ }^{\circ} \mathrm{C}$, respectively. These important weight losses are related to the decomposition of the residual organic material that corresponds to a breakaway of the polymeric chains formed by the polyesterification reaction as well as to the decomposition of nitrates wastes. ${ }^{27,28}$ This process occurs with an important exothermic phenomenon, as pointed out in the DTA curves.

From the results of thermal analyses of $\mathrm{Cu}-\mathrm{Al}$ samples, one can note a shift to lower temperatures of the complete 


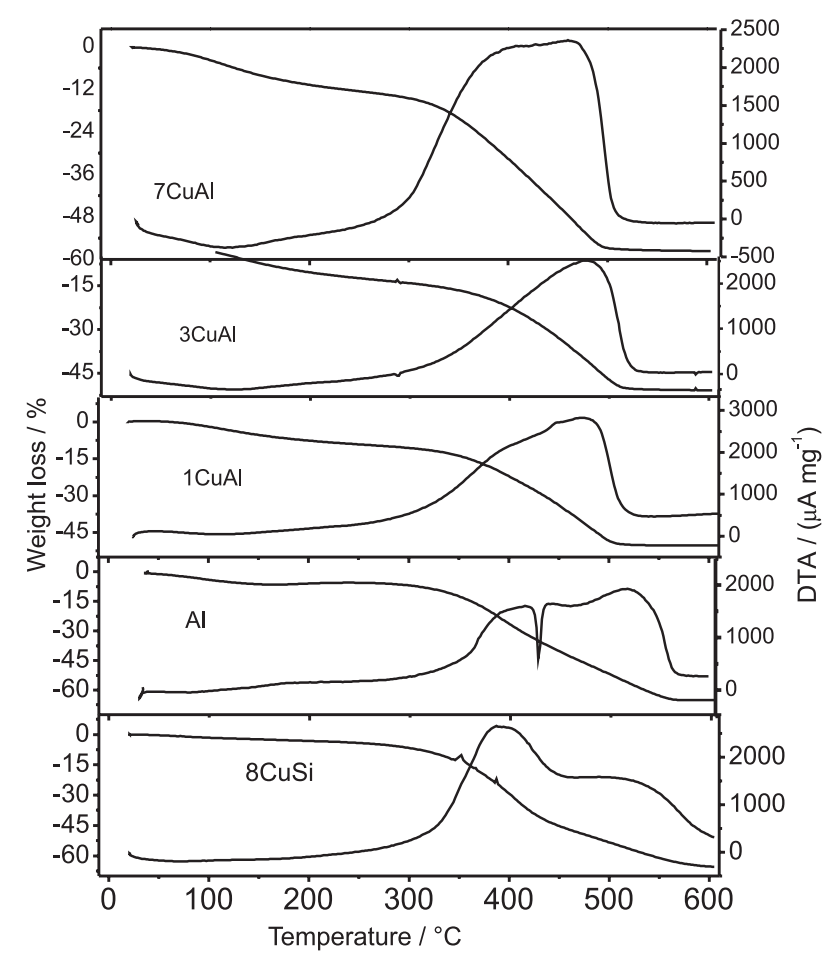

Figure 1. Thermal analysis: TGA profile and the respective DTA.

carbon elimination. This suggests that copper might catalyze the elimination of the organic precursors. However, this seems to be true only for the $\mathrm{CuAl}$ system, since over $\mathrm{CuSi}$, the carbon release was observed up to $600{ }^{\circ} \mathrm{C}$.

This shift in the temperature events can influence the texture and morphology of the samples. Employing organic compounds (CA and EG) in the preparation of the catalysts, which are removed as volatile materials during the calcination steps, probably results in cavities formations and simultaneous formation of the oxides structure. The textural properties of the materials (specific surface areas, pores diameter and pores volume) and the structural features of the final oxides are most closely related to the calcination process.

\section{X-Ray diffraction}

The X-ray diffraction patterns are presented in Figure 2. It is observed that the samples $\mathrm{Al}$ and $1 \mathrm{CuAl}$ are poorly crystalline materials and present $\mathrm{X}$-ray patterns of an amorphous solid. Nevertheless, the $2 \theta$ degree value of the broader peaks (18.6, 20.4, 40.6 and 53.3 degrees) and their relative intensities suggest the $\beta-\mathrm{Al}(\mathrm{OH})_{3}$ phase formation (JCPDS 00-008-0096) for the $3 \mathrm{CuAl}$ and $\mathrm{Al}$ solids. On the other hand, the samples $3 \mathrm{CuAl}, 7 \mathrm{CuAl}$ and $8 \mathrm{CuSi}$ display the formation of a single $\mathrm{Cu}$ phase (CuO, JCPDS 04-006-2679).

The $\mathrm{CuO}$ crystallites sizes of the samples were calculated from the XRD patterns using the Debye-Scherrer

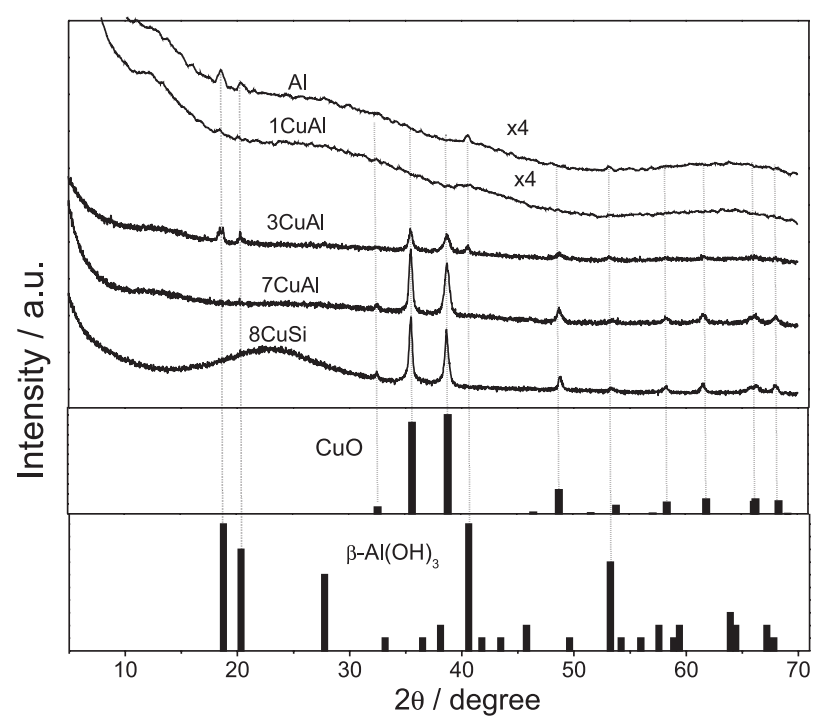

Figure 2. X-Ray diffraction profile of the samples after the calcination at $500{ }^{\circ} \mathrm{C}$.

formula. The results indicate the comparable sizes of crystalline $\mathrm{CuO}$ phase with average crystallites sizes of 24.6, 23.5 and $26.1 \mathrm{~nm}$ for $3 \mathrm{CuAl}, 7 \mathrm{CuAl}$ and $8 \mathrm{CuSi}$, respectively. Furthermore, one can note that the $\mathrm{Cu}$ loading increase does not result in larger $\mathrm{CuO}$ crystallites, which do not seem to depend on the nature of the support, $\mathrm{Si}$ or $\mathrm{Al}$ oxides. This probably accounts for the synthesis method which prevents ionic interactions between the mineral precursors caused by the chelating properties of citric acid as regards to the $\mathrm{Cu}$ cations. Moreover, the relative hightemperature calcination, $500{ }^{\circ} \mathrm{C}$, as regards to the sintering ability of copper might also contribute to the close $\mathrm{Cu}$ crystallites sizes obtained for the different systems.

\section{Specific surface area results}

The nitrogen adsorption/desorption isotherms are presented in Figure 3. The samples $\mathrm{Al}, 1 \mathrm{CuAl}, 3 \mathrm{CuAl}$ and $7 \mathrm{CuAl}$ showed similar isotherms characteristic of mesoporous materials (type II according to IUPAC classification and $\mathrm{H} 3$ hysteresis loop). This is usually assigned to slit-shaped pores due to aggregates of particles. On the other hand, the sample $8 \mathrm{CuSi}$ presents isotherms type IV, characteristic of mesoporous catalyst (H2 hysteresis loop). Type $\mathrm{H} 2$ loop indicates that the pore structure is complex and tend to be made of interconnected networks of pores with different sizes and shapes. ${ }^{29}$ These differences are confirmed by the pores diameter distribution (Barrett-Joyner-Halenda (BJH) method).

Table 1 lists the specific surface area $\left(\mathrm{S}_{\mathrm{BET}}\right)$, total pore volume $(\mathrm{Vp})$ and average pores diameter $(\mathrm{Dp})$ of solids. The increase of the copper loading in the $\mathrm{Al}$ oxides solids provides samples with improved textural features. 


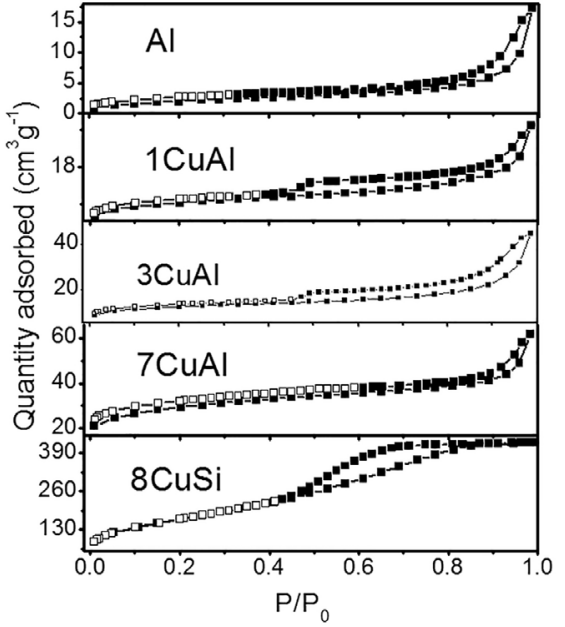

Figure 3. $\mathrm{N}_{2}$ adsorption/desorption isotherms of the catalysts.

$8 \mathrm{CuSi}$ possesses a significant higher specific surface area $\left(603 \mathrm{~m}^{2} \mathrm{~g}^{-1}\right)$ and total pore volume $\left(0.6 \mathrm{~cm}^{3} \mathrm{~g}^{-1}\right)$, in comparison with the other catalysts $(\mathrm{Al}, 1 \mathrm{CuAl}, 3 \mathrm{CuAl}$ and $7 \mathrm{CuAl}$ ) which have specific surface areas lower than $100 \mathrm{~m}^{2} \mathrm{~g}^{-1}$, however, the materials are mesoporous in all cases, with pore size of $40.0 \AA$. Thus, it appears that the nature of the component used as support influences greatly the textural properties, probably caused by the type of inorganic precursor. Indeed, the $\mathrm{Al}$ and $\mathrm{Si}$ precursors are distinct, $\mathrm{Al}$ nitrate and tetraethylorthosilicate (TEOS), respectively. Thus, starting from TEOS in the case of silica might, most likely, prevents the formation chelated $\mathrm{Si}$ specie with citric acid and thereafter a different process might have occurred. These differences were also observed in the TGA-DTA results (Figure 1).

\section{XPS analysis}

Quantitative XPS analysis of the calcined samples show that the superficial atomic concentration of copper increased from $3 \mathrm{CuAl}$ to $7 \mathrm{CuAl}$, logically. Note that the $\mathrm{Cu}$ coverage of $7 \mathrm{CuAl}$ and $8 \mathrm{CuSi}$ are very close. Moreover, the results indicate that the $\mathrm{Cu}$ coverage was not changed significantly after the reduction step at $250{ }^{\circ} \mathrm{C}$ (Table 2). These results, combined with the isotherms data, indicate that despite the sample $8 \mathrm{CuSi}$ have greater surface area related to the solid $7 \mathrm{CuAl}$ the $\mathrm{Cu}$ surface coverage is very similar, probably indicating that the catalytic performance for these two catalysts will be very close for reactions in which copper is the major active site.

For $8 \mathrm{CuSi}$, the $\mathrm{Cu} 2 \mathrm{p}_{3 / 2}$ photoelectron spectrum present a main peak observed at $932.9 \mathrm{eV}$, and satellite lines at higher binding energy values, characteristic of $\mathrm{Cu}^{\mathrm{II}}$ oxydation state (Figure 4). The binding energy of the main $\mathrm{Cu} 2 \mathrm{p}_{3 / 2}$ peak is in good agreement with the presence of $\mathrm{CuO}$, as observed in XRD results (Figure 2).

For $3 \mathrm{CuAl}$ and $7 \mathrm{CuAl}$, the $\mathrm{Cu} 2 \mathrm{p}_{3 / 2}$ photoelectron spectrum shows a main component at $932.9 \mathrm{eV}$ with a shoulder at higher binding energy, $935 \mathrm{eV}$, which represents ca. $30 \%$ of the total peak area. One can notice that for $3 \mathrm{CuAl}$ and $7 \mathrm{CuAl}$, the relative intensity of the satellite peaks are higher compared to $8 \mathrm{CuSi}$ (Figure 4).

Table 1. Chemical analyses, textural properties and amount of carboneous deposits on the spent catalysts

\begin{tabular}{|c|c|c|c|c|c|}
\hline Sample & $\mathrm{Cu} / \mathrm{wt} . \%$ & $\mathrm{~S}_{\mathrm{BET}} /\left(\mathrm{m}^{2} \mathrm{~g}^{-1}\right)$ & $\mathrm{Vp} /\left(\mathrm{cm}^{3} \mathrm{~g}^{-1}\right)$ & $\mathrm{Dp} / \mathrm{nm}$ & C/wt. $\%$ \\
\hline $\mathrm{Al}$ & - & 7 & 0.03 & 15.3 & 4.2 \\
\hline $1 \mathrm{CuAl}$ & 0.66 & 32.0 & 0.04 & 8.5 & 6.5 \\
\hline $3 \mathrm{CuAl}$ & 3.16 & 41.4 & 0.06 & 10.6 & 5.3 \\
\hline $7 \mathrm{CuAl}$ & 6.75 & 99.2 & 0.06 & 8.2 & 20.6 \\
\hline $8 \mathrm{CuSi}$ & 7.80 & 603.6 & 0.6 & 4.0 & 7.0 \\
\hline
\end{tabular}

$\mathrm{S}_{\mathrm{BET}}$ : Specific surface area; Vp: total pore volume; Dp: average pores diameter; C: Carbon content obtained from TGA analysis of spent catalysts recovered after $5 \mathrm{~h}$ of recation in standard conditions.

Table 2. XPS analyses of calcined and reduced samples: binding energies of $\mathrm{Cu} 2 \mathrm{p}_{3 / 2}, \mathrm{Cu}$ superficial atomic concentrations

\begin{tabular}{|c|c|c|c|c|}
\hline \multirow{2}{*}{ Catalyst } & \multicolumn{3}{|c|}{$\mathrm{ElCu} 2 \mathrm{p}_{3 / 2}(\mathrm{eV})$} & \multirow{2}{*}{$\begin{array}{l}\mathrm{Cu} \text { superficial atomic } \\
\text { concentration / atom\% }\end{array}$} \\
\hline & $\mathrm{Cu}^{\mathrm{II}}$ & $\mathrm{Cu}^{\mathrm{II}}$ & $\mathrm{Cu}^{\mathrm{I} / 0}$ & \\
\hline 3CuAl calcined & 934.8 & $\begin{array}{c}932.7 \\
\text { main component }\end{array}$ & - & 0.66 \\
\hline $3 \mathrm{CuAl}$ reduced & - & - & 932.1 & 0.51 \\
\hline 7CuAl calcined & 934.8 & $\begin{array}{c}932.8 \\
\text { main component }\end{array}$ & - & 0.80 \\
\hline 7CuAl reduced & - & - & 931.9 & 0.90 \\
\hline 8CuSi calcined & - & 933.5 & - & 0.88 \\
\hline $8 \mathrm{CuSi}$ reduced & - & - & 932.7 & 0.87 \\
\hline
\end{tabular}



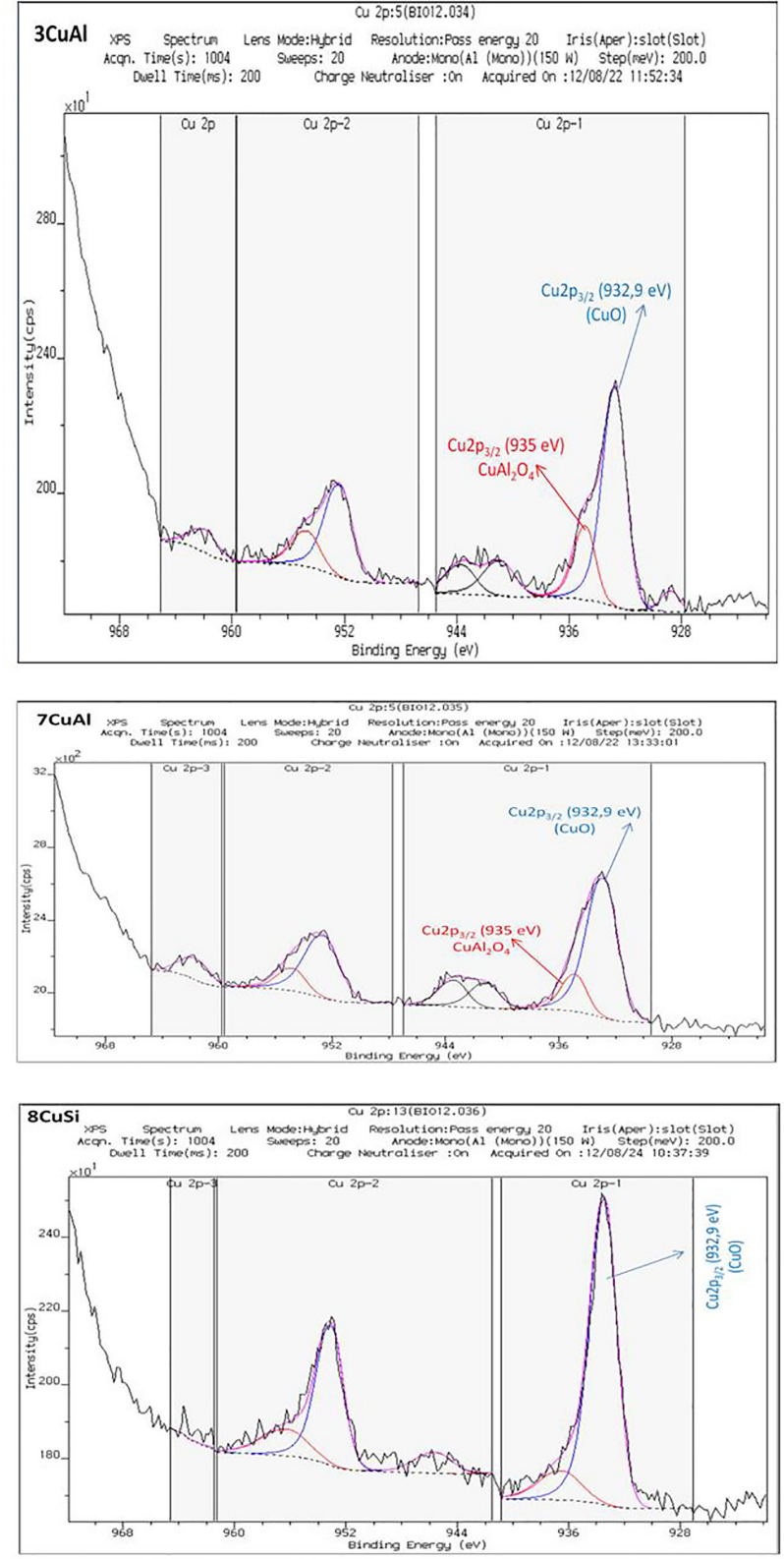

Figure 4. $\mathrm{Cu} 2 \mathrm{p}_{3 / 2}$ photoelectron spectra for calcined samples, $3 \mathrm{CuAl}$, $7 \mathrm{CuAl}$ and $8 \mathrm{CuSi}$.

One can recall that it was previously reported that the intensity of the satellite bands $\left(\mathrm{I}_{\mathrm{sat}}\right)$ compared to that of the main peak $\left(\mathrm{I}_{\mathrm{mp}}\right)$, was correlated with the $\mathrm{Cu}^{2+}$ symmetry. Thus, for $\mathrm{CuO}$ where $\mathrm{Cu}^{2+}$ is in a square planar symmetry, an $\mathrm{I}_{\mathrm{sal}} / \mathrm{I}_{\mathrm{mp}}$ value close to 0.5 was reported when $\mathrm{Cu}^{2+}$ is in a spinel structure; in a tetrahedral environment, a higher relative intensity of the satellite bands was measured up to 0.8. ${ }^{30,31}$ Thus, for $7 \mathrm{CuAl}$, the presence of the shoulder at $935 \mathrm{eV}$, a higher binding energy value than that tabulated for $\mathrm{CuO}$ and already reported for the spinel $\mathrm{CuCr}_{2} \mathrm{O}_{4}$ together with the presence of more intense satellite bands, strongly support the partial insertion of $\mathrm{Cu}$ in a spinel phase such as $\mathrm{CuAl}_{2} \mathrm{O}_{4}$ which would exist, at least, on the surface. After in situ reduction at $250^{\circ} \mathrm{C}$, the satellite peaks disappeared logically and the $\mathrm{Cu} 2 \mathrm{p}_{3 / 2}$ photoelectron spectra present a single finer peak at ca. $932 \mathrm{eV}$ for all samples, characteristic of the reduced species $\mathrm{Cu}^{1}$ and/or $\mathrm{Cu}^{0}$ (Figure 5). Unfortunately, we failed to discriminate between the formation of metallic copper, $\mathrm{Cu}^{0}$ or $\mathrm{Cu}^{\mathrm{I}}$ species based on the kinetic energy of the auger electrons $L_{3} \mathrm{M}_{4.5} \mathrm{M}_{4.5}$, because the signals were too broad, which precludes any reliable measure. Thus, temperature programmed reduction analysis is indispensable to confirm the copper oxidation state after the reduction step at $250{ }^{\circ} \mathrm{C}$.

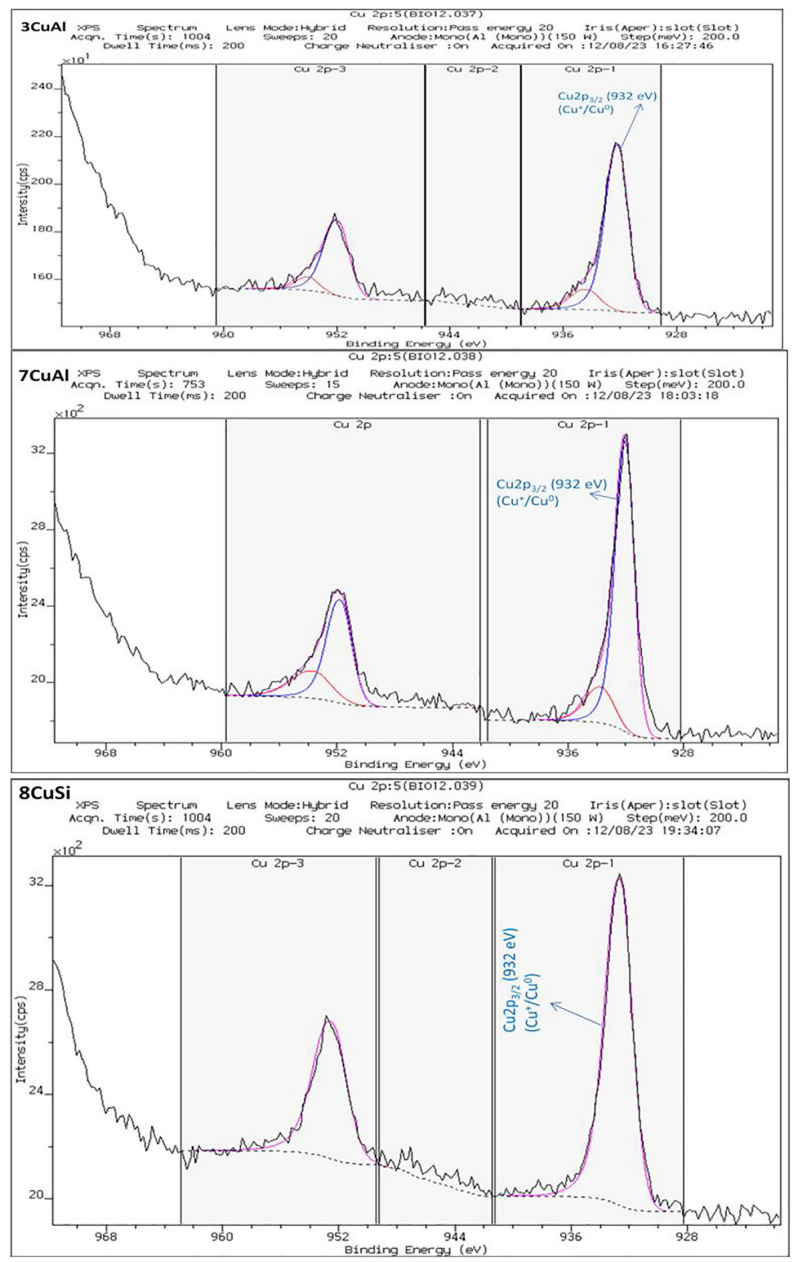

Figure 5. Cu2 $\mathrm{p}_{3 / 2}$ photoelectron spectra for reduced samples, $3 \mathrm{CuAl}$, $7 \mathrm{CuAl}$ and $8 \mathrm{CuSi}$.

\section{Temperature programmed reduction (TPR)}

$\mathrm{H}_{2}$-TPR profiles of different samples presented a single band of hydrogen consumption (Figure 6). The TPR results showed the influence of the support ( $\mathrm{Al}$ or $\mathrm{Si}$ oxide) on the reducibility of copper oxide, which is evidenced for low amounts of $\mathrm{CuO}$. The solid $1 \mathrm{CuAl}$ with the slightest amount of copper oxide has a higher 
reduction temperature compared to the catalyst $7 \mathrm{CuAl}$, probably due to the greater interaction between copper oxide and the $\mathrm{Al}$ support.

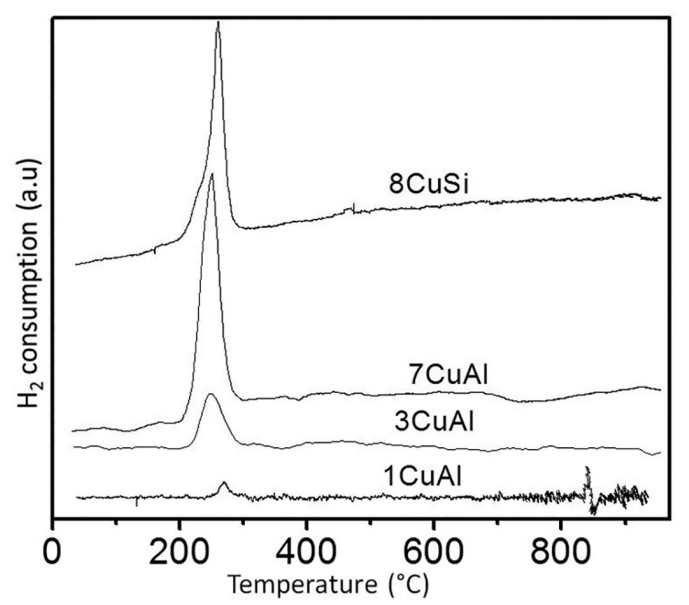

Figure 6. Temperature programmed reduction curves of the catalysts.

Furthermore, as expected, the intensity of $\mathrm{Cu}^{2+}$ reduction peaks increase with the increase of copper amount, confirming that the formed peak is incontestably related to the reduction of $\mathrm{CuO}$ (majority) and copper spinel (minority), as seen in the X-ray diffractograms (Figure 2) and XPS results (Figures 4 and 5).

On the other hand, the solid $8 \mathrm{CuSi}$ shows the formation of a shoulder around $220^{\circ} \mathrm{C}$ and an intense band at $255^{\circ} \mathrm{C}$. The shoulder at $220^{\circ} \mathrm{C}$ may indicate the presence of $\mathrm{Cu}^{+}$, while the second one may be due to the reduction of $\mathrm{Cu}^{2+}$ species to $\mathrm{Cu}^{0}$; again in agreement with the XRD and XPS results. $\mathrm{H}_{2}$-TPR results confirmed the presence of $\mathrm{Cu}^{\mathrm{I}}$ and $\mathrm{Cu}^{0}$ after pre-treatment in hydrogen atmosphere at $250{ }^{\circ} \mathrm{C}$ before the reaction, considering that the copper oxide was not completely reduced at this temperature.

However, based on published work ${ }^{32}$ and considering that there was the formation of copper oxide nanoparticles as observed in the X-rays results, one cannot rule out the possibility that the observed shoulder is related to highly dispersed $\mathrm{CuO}$ species (more easily reducible) and the second peak is concerning the reduction of $\mathrm{CuO}$ bulk (more difficult to reduce). Additionally, it is known that a copper oxide particle located within the pores of the support shows a harder reduction process compared to a particle positioned on the external surface. Thus, this may also be linked with the textural properties (Figure 3).

It is important to report that it is given a great attention for the change of the catalytic phase and the oxidation state of copper during the glycerol conversion. ${ }^{33-35}$ It was already mentioned that the presence of $\mathrm{Cu}^{0} / \mathrm{Cu}^{\mathrm{I}}$ and the synergetic effect of $\mathrm{Cu}^{0}$ and $\mathrm{Cu}^{+}$may favor the conversion of glycerol to acetol and 1,2-propanediol under specific reaction conditions..$^{36-41}$ Xiao et al. ${ }^{33}$ proposed that the metal copper was mainly responsible for the activation of hydrogen, while $\mathrm{Cu}^{+}$was for dehydration due to the presence of Lewis acid sites. The dehydration also takes place at metallic copper site, since glycerol may also be dehydrated to acetol. Thus, according to the $\mathrm{H}_{2}$-TPR and XPS results, which indicate the presence of $\mathrm{Cu}^{0}$ and $\mathrm{Cu}^{+}$ in the applied reaction conditions, it is expected that the solids present interesting catalytic properties in the glycerol conversion to acetol and 1,2-propanediol.

Furthermore, it is probable that under the employed reaction conditions the acetol selectivity is larger compared to the 1,2-propanediol selectivity, since the reaction rate in the hydrogenation is much lower compared to the reaction rate of the dehydration of glycerol. Under atmospheric pressure and elevated temperature the 1,2-propanediol production is disadvantaged, since the hydrogenation of acetol is an exothermic reaction. ${ }^{33-35,40,41}$

\section{Catalytic activity}

The catalytic performances of the samples are depicted in Figure 7a (conversion of glycerol) and Figure 7b (acetol selectivity). The samples with the highest copper loading are active and highly selective, with acetol selectivity higher than $90 \%(7 \mathrm{CuAl}$ and $8 \mathrm{CuSi})$ and an initial glycerol conversion higher than $85 \%$. Note that if these two catalysts present different BET surface area, the reduced samples present similar $\mathrm{Cu}$ surface as determined by XPS analysis (Figure 4 and Table 2). This similar copper surface may be correlated with the same initial glycerol conversion measured on $7 \mathrm{CuAl}$ and $8 \mathrm{CuSi}$. However, the catalytic activities of these two catalysts show distinct evolutions with time on stream. The $8 \mathrm{CuSi}$ sample presents a short initial deactivation, however, its catalytic activity is stabilized after $2 \mathrm{~h}$ with glycerol conversion and acetol selectivity of 66 and $96 \%$, respectively. Other products

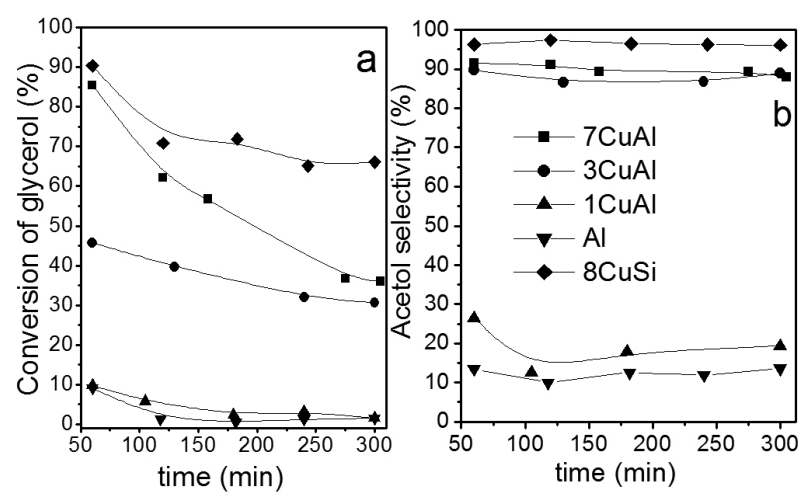

Figure 7. Catalytic performance as a function of time for the catalysts: (a) conversion of glycerol; (b) acetol selectivity. 
are observed in low amount, such as 1,2-propanediol, propanoic acid and small amounts of acetic acid.

Among the Al- $\mathrm{Cu}$ series, $7 \mathrm{CuAl}$ exhibits the best catalytic properties (Figure 7). In particular, one can notice that the initial activity measured on $7 \mathrm{CuAl}$ and $3 \mathrm{CuAl}$ are closely correlated with the $\mathrm{Cu}$ surface measured by XPS on the reduced samples. On the other hand, pure aluminum oxide is almost inactive and less selective for hydroxyacetone. Its behavior is comparable to $1 \mathrm{CuAl}$, with less than 1 wt. \% of $\mathrm{Cu}$.

It is important to highlight that when the reactions are performed under $\mathrm{N}_{2}$ atmosphere, all the samples exhibited very poor activities.

All these results strongly suggest that reduced copper species are the active species for the selective conversion of glycerol to acetol under the reaction condition, while the $\mathrm{Al}$ and Si supports would not play a major role in acetol selective formation in agreement with previous reports from Bienholz et $a l .{ }^{22}$ However, copper metal sites combined with an appropriate support can play a major role in the activity, selectivity and stability of samples. ${ }^{21}$

In spite of the equivalent initial glycerol conversion for $7 \mathrm{CuAl}(86 \%)$ and $8 \mathrm{CuSi}(90 \%)$ well correlated to their copper surface (XPS results), 7CuAl solid shows a continuous deactivation during the course of the reaction while $8 \mathrm{CuSi}$ is rapidly stabilized. $3 \mathrm{CuAl}$ shows also a deactivation, but less pronounced than 7CuAl (Figure 7). Hence, one can think that the gradual catalyst deactivation is probably caused by the acidity of the aluminum based support, which leads to higher carbon deposition.

Calorimetric measurements are generally considered as a reliable technique to measure the acidic strength of solid acids in addition to the quantification of the number of acid sites when isotherms of the acid probe molecules adsorption are recorded in parallel. Therefore, in order to confirm that the pronounced deactivation of $7 \mathrm{CuAl}$ compared to $8 \mathrm{CuSi}$ is due to the higher acidity of the $\mathrm{Al}$ support compared to the $\mathrm{Si}$ support, the reduced samples $\mathrm{Al}, 7 \mathrm{CuAl}$ and $8 \mathrm{CuSi}$ were analyzed by calorimetry of $\mathrm{NH}_{3}$ adsorption (Figure 8).

The calorimetry results presented in Figures $8 \mathrm{a}$ and $8 \mathrm{~b}$ confirm that the samples containing aluminium oxide ( $\mathrm{Al}$ and $7 \mathrm{CuAl}$ ) show superior acidity compared to the silica-based oxide $(8 \mathrm{CuSi})$. If the three solids present a few amount of strong acid sites with a differential heat of $\mathrm{NH}_{3}$ adsorption higher than $160 \mathrm{~kJ} \mathrm{~mol}^{-1}$, the specific amounts of acid sites of intermediate strength, with a differential heat of $\mathrm{NH}_{3}$ adsorption higher than $110 \mathrm{~kJ} \mathrm{~mol}^{-1}$ are significantly higher for the $\mathrm{Al}$ based solids. The calorimetric curve of $8 \mathrm{CuSi}$ which shows a rapid decrease of the differential heat of $\mathrm{NH}_{3}$ adsorption give evidences of the poor acidity of the silica support, as expected. On the other hand, it was observed
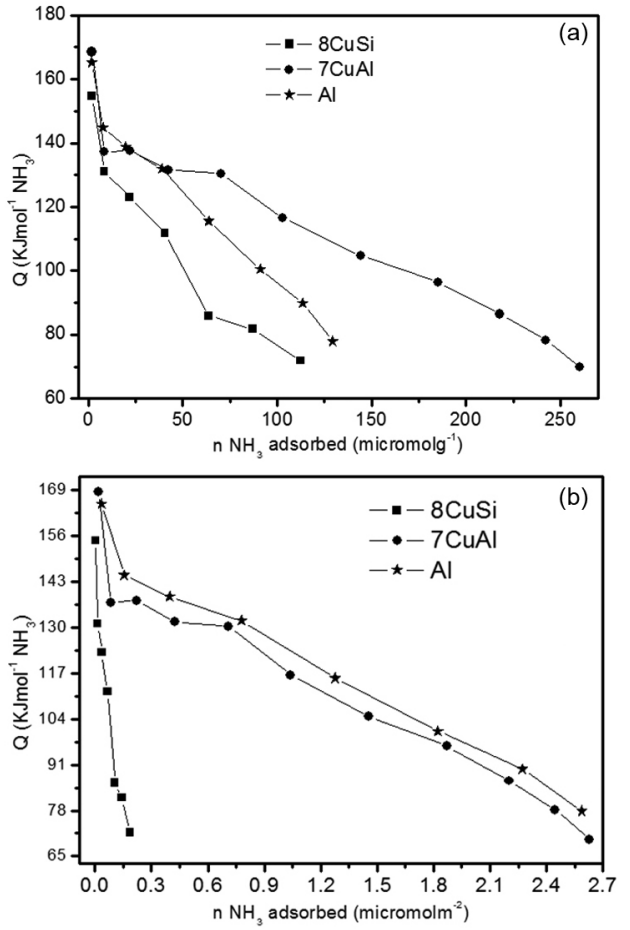

Figure 8. Differential heat of $\mathrm{NH}_{3}$ adsorption as a function of $\mathrm{NH}_{3}$ coverage: (a) micromol of ammonia adsorbed per gram of the catalyst; (b) micromol of ammonia adsorbed per meter square of the catalyst.

for the catalysts based on Al, a larger number of acid sites, but the surface is heterogeneous in term of acid strength, according to the progressive decrease of the differential heat of $\mathrm{NH}_{3}$ adsorption with the $\mathrm{NH}_{3}$ coverage. Furthermore, it is observed that $7 \mathrm{CuAl}$ and the $\mathrm{Cu}$ free $\mathrm{Al}$ solid present similar calorimetric curves when the amount of absorbed $\mathrm{NH}_{3}$ is expressed per $\mathrm{m}^{2}$. This indicates that reduced $\mathrm{Cu}$ species do not provide additional acid sites nor modify the intrinsic acidic features of the support in a significant way.

To further consolidate the cause of deactivation during the reaction, the spent catalysts were analyzed by TGA and the results are presented in Table 1. The results indicate the marked higher carbon amount determined on $7 \mathrm{CuAl}$ compared to $8 \mathrm{CuSi}, 20.6$ against $7.0 \mathrm{wt} \%$. Therefore, this result confirms the origin of the deactivation. The acidity of the Al based catalyst favors the formation of carboneous deposits on the surface due to its acidity, which may indirectly hinder the reduced copper role in the glycerol dehydration due to the covering of active sites by carbon. Thus, it is essential to control the acid-metallic properties in order to obtain good results of catalytic activity, selectivity and especially stability.

\section{Conclusions}

In this paper, mesoporous mixed copper-aluminum and copper-silicium oxides were synthesized by the polymeric 
precursor method and tested as catalysts in the gas-phase conversion of glycerol to acetol in $\mathrm{H}_{2}$ atmosphere, in mild temperature conditions, $250{ }^{\circ} \mathrm{C}$ and under atmospheric pressure. The selective glycerol conversion to acetol depends directly on the copper surface as determined by XPS analysis performed on in situ reduced solids. The nature of the support component, Si or Al, does not influence the initial catalytic performances, using the same copper content with a similar copper surface, but affect the stability of the catalytic systems. While $\mathrm{Cu}$ supported on the silica support exhibits a good catalytic stability after $2 \mathrm{~h}$ of reaction, the $\mathrm{Cu}-\mathrm{Al}$ systems exhibit continuous deactivations which were correlated to the acidity of the Al support as clearly shown by calorimetry of $\mathrm{NH}_{3}$ adsorption. The greater acidity for the acid Al support provides a higher carbon deposit compared to Si neutral support, justifying the sharp deactivation for the $7 \mathrm{CuAl}$ solid due to covering of the active sites by coke.

The results of XPS and $\mathrm{H}_{2}$-TPR analysis together with the results of calorimetry support the mechanism in which the active species for glycerol dehydration to acetol is a reduced $\mathrm{Cu}$ species $\mathrm{Cu}^{\mathrm{I}}$ and/or $\mathrm{Cu}^{0}$. The acid sites present on the $\mathrm{Cu}$ based catalyst do not participate effectively in the dehydration step for the experimental conditions used, playing a secondary role, but they have a negative role on the catalyst stability due to the excessive carbon deposit.

Therefore, the proposed mechanism should most likely proceed via homolytic cleavage of the primary $\mathrm{C}-\mathrm{OH}$ of glycerol by the reduced copper species. This model, already proposed, ${ }^{21,22}$ is in good agreement with the reaction product, acetol, which can hardly be formed via a primary carbenium ion formation as intermediate which is thermodynamically stable under atmospheric pressure and mild temperature.

\section{Acknowledgments}

The authors acknowledge the Universidade Federal do Ceará (UFC) and Institut de Recherches sur la Catalyse et l'Environnement de Lyon (IRCELYON) in Lyon-France.

\section{References}

1. Huber, G. W.; Iborra, S.; Corma, A.; Chem. Rev. 2006, 106, 4044.

2. Corma, A.; Iborra, S.; Velty, A.; Chem. Rev. 2007, 107, 2411.

3. Akiyama, M.; Sato, S.; Takahashi, R.; Inui, K.; Yokota, M.; Appl Catal., A 2009, 371, 60.

4. Liu, Z.; Wang, J.; Kang, M.; Yin, N.; Wang, X.; Yisheng, T.; Zhub, Y.; J. Braz. Chem. Soc. 2014, 25, 152.

5. Maris, E. P.; Davis, R. J.; J. Catal. 2007, 249, 328.
6. Satyanarayana, M.; Pudi, P. P.; Shashi Kumara, S.; Sarkar, B.; J. Braz. Chem. Soc. 2015, 26, 1551.

7. Huang, Z.; Cui, F.; Xue, J.; Zuo, J.; Chen, J.; Xia, C.; Catal. Today 2012, 18, 342.

8. Lima, C. L.; Vasconcelos, S. J. S.; Filho, J. M.; Neto, B. C.; Rocha, M. G. C.; Bargiela, P.; Oliveira, A. C.; Appl Catal, A 2011, 399, 50.

9. Carolina, F. M.; Pestana, A. C. O.; Guerra, G. B. F.; Cássia, C. T.; Mota, J. A.; J. Braz. Chem. Soc. 2013, 24, 100.

10. Raju, G.; Reddy, P. S.; Reddy, B. M.; The Open Catal. J. 2011, 4,83 .

11. Kim, Y.; Jurg, K. D.; Park, E. D.; Appl. Catal., B 2011, 107, 177.

12. Kinage, A. K.; Upare, P. P.; Kasinathan, P.; Hwang, Y. K.; Chang, J. S.; Catal. Comm. 2010, 11, 620.

13. Dasari, M. A.; Kiantsimkal, P. P.; Sutterlin, W. R.; Supped, G. J.; Appl. Catal., A 2005, 281, 225.

14. Chiv, C. W.; Dasari, M. A.; Suppes, G. J.; Sutterlin, W. R.; AIChe J. 2006, 22, 3543.

15. Valentini, A.; Carreño, N. L. V.; Leite, E. R.; Longo, E.; Appl. Catal., A 2006, 310, 174.

16. Braga, T. P.; Teixeira, C. V.; Pinheiro, A. N.; Valentini, A.; Appl. Catal., A 2009, 366, 193.

17. Chin, C. W.; Tekeci, A.; Sutterlin, W. R.; Ronco, J. M.; Suppers, G. J.; AIChe J. 2008, 54, 2456.

18. Mane, R. B.; Ghalwaddkar, A. A.; Hengne, A. M.; Suryawanski, Y. R.; Rode, C. V.; Catal. Today 2011, 164, 447.

19. Feng, Y.; Yin, H.; Wang, A.; Shen, L.; Yu, L.; Jiang, T.; Chem. Eng. J. 2011, 168, 403.

20. Huang, L.; Zha, Y.; Zheng, H.; Ding, G.; Li, Y.; Catal. Lett. 2009, 131, 312.

21. Sato, S.; Akiyama, M.; Takahashi, R.; Hara, T.; Inui, K.; Yokota, M.; Appl. Catal., A 2008, 347, 186.

22. Bienholz, A.; Hofman, H.; Claus, P.; Appl. Catal., A 2011, 391, 153.

23. Piertron, J. J.; Stroud, R. M.; Rolison, D. R.; Nano Lett. 2002, 2, 545 .

24. Beaudet, L.; Hossain, K. Z.; Mercier, L.; Chem. Mater. 2003, $15,327$.

25. Braga, T. P.; Sales, B. M. C.; Pinheiro, A. N.; Valentini, A.; Cata. Scien. Tec. 2011, 1, 1383.

26. Ries, A.; Simões, A. Z.; Cilense, M.; Zaghete, M. A.; Varela, J. A.; Mater. Charact. 2003, 50, 217.

27. Forti, J. C.; Olivi, P.; de Andrade, A. R.; Electrochim. Acta 2001, $47,913$.

28. El-Shobaky, G. A.; Turky, A. M.; Mostafa, N. Y.; Mohamed, S. K.; J. Alloys Compd. 2010, 493, 415.

29. Frost, D. C.; McDowell, C. A.; Ishitani, A.; Mol. Phys. 1974, 24,861 .

30. D’Huysser, A.; Wrobel, G.; Bonnelle, J. P.; Nouv. J. Chim. 1982, $6,437$. 
31. Essayem, N.; Barrault, J.; Guimon, C.; Appl. Catal., A 1993, 102, 137.

32. Luo, M.; Xie, Y.; J. Mol. Catal. A: Chem. 2005, 239, 243.

33. Xiao, Z.; Wang, X.; Xiu, J.; Wang, Y.; Williams, C. T.; Liang, C.; Catal. Today 2014, 234, 200.

34. Dam, J. T.; Hanefeld, U.; ChemSusChem 2011, 4, 1017.

35. Baertsch, C. D.; Komala, K. T.; Chua, Y.; Iglesia, E.; J. Catal. 2002, 205, 44.

36. Mane, R. B.; Yamaguchi, A.; Malawadkar, A.; Shirai, M.; Rode, C. V.; RSC Adv. 2013, 3, 16499.

37. Velasquez, M.; Santamaria, A.; Batiot-Dupeyrat, C.; Appl. Catal., B 2014, 160, 606.
38. Sato, S.; Akiyama, M.; Takahashi, R.; Hara, T.; Inui, K.; Yokota, M.; Appl. Catal., A 2008, 347, 186.

39. Yue, H.; Zhao, Y.; Ma, X.; Gong, J.; Chem. Soc. Rev. 2012, 41, 4218.

40. Braga, T. P.; Essayem, N.; Valentini, A.; RSC Adv. 2015, 5, 93394.

41. Braga, T. P.; Essayem, N.; Valentini; Quim. Nova. 2016, in press, DOI: $10.5935 / 0100-4042.20160074$.

Submitted: February 2, 2016

Published online: May 3, 2016 